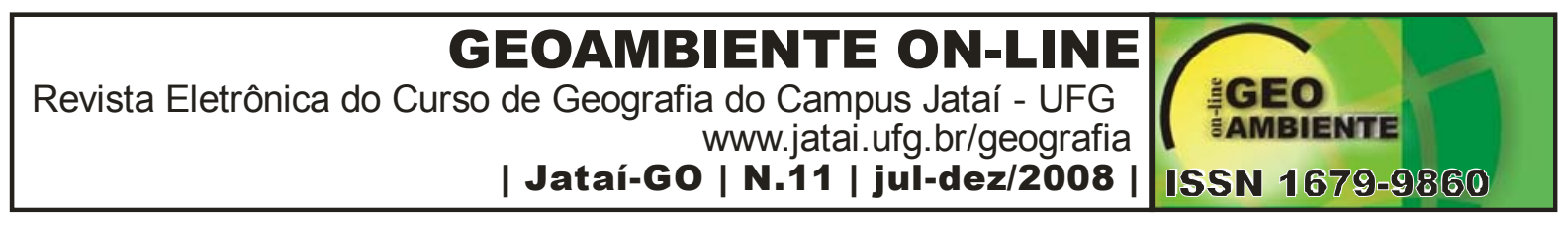

\title{
POVOS DA AMAZÔNIA: JURUNA - MAKUNA - KRAHÔ
}

\author{
Marcos Clodoaldo Morais Garcia ${ }^{1}$ \\ (1 - Docente da Universidade Estadual de Goiás - Campus de Quirinópolis \\ Mestre em Ciência do Ambiente, E-mail: $\underline{\text { momg2002@ibest.com.br) }}$
}

\section{Resumo}

A diversidade cultural entre os homens ocidentais e não ocidentais são gritantes, constata também as similaridades e as diferenças entre os povos indígenas de uma mesma região: Krahô, Makuna e Juruna, exemplificando o seu histórico e localização, que são ambos da região Amazônica Brasileira, sendo que os Makuna e Juruna vivem em região de floresta amazônica, próximos de grandes rios, enquanto que os Krahô vivem em região de cerrado, próximos de pequenos rios; tratando-se da cosmologia e xamanismo, os Krahô e os Makuna, identificam os elementos do meio ambiente pelo sistema anímico, já os Juruna, identificam esses mesmos elementos pela modalidade totêmica; a ecologia e a caça são semelhantes para todos, sendo que a caça, a pesca e a coleta de frutos são feitas de acordo com o que a natureza lhes oferece, sendo que a mandioca é a planta mais cultivada e apreciada por ambos os povos.

Palavras-chave: Índios; Brasil; Amazônia; Meio Ambiente; Ecologia Simbólica.

\begin{abstract}
PEOPLES OF AMAZON: JURUNA - MAKUNA - KRAHÔ

The culture diversity between the occidental and not occidental men is clamorous, also evidences the similarities and the differences between the aboriginal peoples of one same region: Krahô, Makuna and Juruna, example its description and localization, that are both of the Brazilian Amazon region, being that the Makuna and Juruna live in region of Amazonian forest, next to great rivers, whereas the Krahô lives in open pasture region, next to small rivers; being about cosmology and xamanismo, the Krahô and the Makuna, identify the elements of the environment for the psychic system, already the Juruna, identifies to these same elements for the totêmica modality; the ecology and the hunting are similar for all, being that the hunting, fish it and the collection of fruits is made in accordance with
\end{abstract}




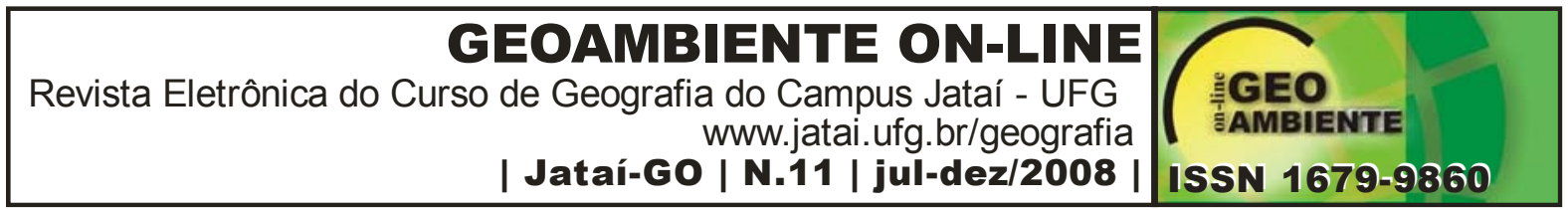

what the nature offers to them, being that the cassava è the plant more cultivated and appreciated by both the peoples.

Key-Words: Indians; Brazil; Amazon; Environment; Symbolic ecology.

\section{1 - ÍNDIOS BRASILEIROS E AMAZÔNICOS}

Para falarmos de Índios do Brasil, é necessário desligarmos do nosso eu cultural, como pesquisador não índio. Segundo (DAMATA, 2000), as ciências sociais estudam fenômenos complexos, situações em planos de causalidade e determinações complicadas, onde a matéria-prima não pode ser isolada e estudada em laboratório, pois estuda eventos humanos, ou seja, tanto o pesquisador quanto a sua vitima compartilham, embora, muitas vezes não se comuniquem, de um mesmo universo das experiências humanas, respeitandose as diferenças e a pluralidade. (AMBIENTE BRASIL, 2000).

Sendo assim, em 1910 foi criado o Serviço de Proteção ao Índio (SPI), chefiado pelo Marechal Cândido Mariano da Silva Rondon - descendente de índios, que trabalhou durante anos para melhorar as condições de vida da população indígena brasileira -dando início ao período de pacificação dos índios e do reconhecimento do direito deles à posse da terra e de viver de acordo com os próprios costumes.

No ano de 1967, foi extinto o SPI, devido a inúmeras denúncias de irregularidades administrativas, após a saída do Marechal. No mesmo ano foi criada em seu lugar, a Fundação Nacional do Índio (FUNAI), que procurou estabelecer uma política de respeito às populações indígenas através de normas de bom relacionamento entre o índio e a nossa sociedade.

Os primeiros índios do Brasil viviam em regime de comunidade. A divisão das tarefas do dia-a-dia era feita por sexo e por idade e todos ajudavam. Os ensinamentos, as práticas, as histórias, a invocação dos espíritos, os cantos e as danças eram transmitidos de geração para geração (MELATTI, 1972).

Os chefes das tribos eram os mais velhos, e eram eles que resolviam problemas como doenças, mortes, desavenças na família e na tribo, atrito entre as tribos vizinhas, guerras e paz. Cada tribo tinha seus próprios costumes seu jeito de viver, de morrer, de construir a aldeia, de governar. A terra não era de um só e sim de todos que nela viviam, não havia demarcações nem comércio. 


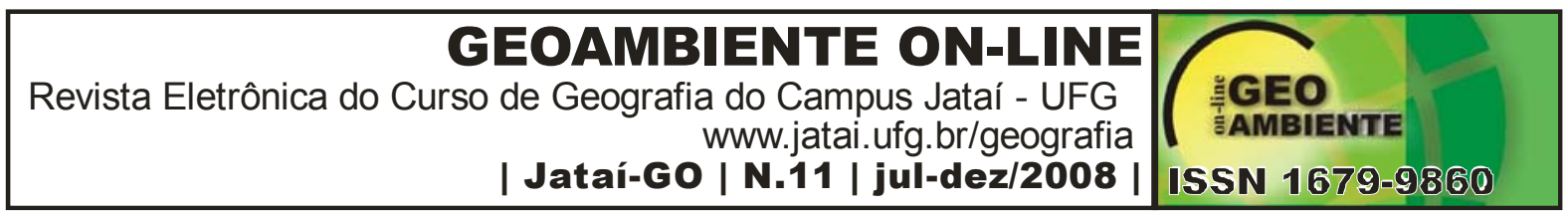

Os primeiros portugueses que chegaram ao Brasil mantiveram um contato amistoso com os índios, pois precisavam deles para trabalhar na extração do pau-brasil e para defender o litoral dos contrabandistas, principalmente franceses. Mas, com o aumento do número de portugueses, as relações do branco com o índio foram se tornando críticas, os índios reagiram porque os portugueses roubavam-lhes as terras, atacavam suas mulheres, tiravam-lhes a liberdade e transmitiam-lhes doenças, algumas vezes causando a morte de todos os habitantes de uma aldeia.

Apesar da resistência, milhares de índios foram escravizados no período colonial pelos portugueses, que usavam armas de fogo para dominar as populações indígenas. Nessa época, os portugueses escravizaram os índios para forçá-los a trabalhar na lavoura canavieira e na coleta de cacau nativo, baunilha, guaraná, pimenta, cravo, castanha-do-pará e madeiras, entre outras atividades.

Não foi apenas no Brasil que os portugueses mataram índios. Também na África e na Ásia eles foram responsáveis pela morte de milhares de seres humanos. Dos aproximadamente 4 milhões de índios que habitavam o Brasil na época da chegada de Cabral, restam hoje mais ou menos 350 mil, sobrevivendo em condições precárias e sob constante ameaça, principalmente dos garimpeiros.

Reduzidos demográfica e sistematicamente, sujeitos às pressões crescentes das frentes de expansão econômica que avançam sobre as terras e os recursos naturais, o futuro dos povos indígenas no Brasil é ainda incerto.

Aos 500 anos após o descobrimento, o Brasil ainda desconhece a imensa diversidade de povos indígenas que ainda vivem no País. Estima-se que hoje existam aproximadamente 210 povos, com vários graus de contato, cerca de 170 línguas e dialetos, distribuídos em todo território brasileiro.

Alguns povos foram descobertos pela FUNAI e conseguiram reconstituir sua própria sociedade. Os índios que hoje vivem no País não falam apenas o Tupi-guarani - tronco lingüístico que abrange 30 nações indígenas - mas, cerca de 170 línguas diferentes, incluindo o Português.

De acordo com AMBIENTE BRASIL (2000), os índios passaram por tempos de matança, escravismo, catequização forçada ou mera indiferença das autoridades. Em 1500, quando os portugueses chegaram ao Brasil, estima-se que haviam por aqui cerca de 4 


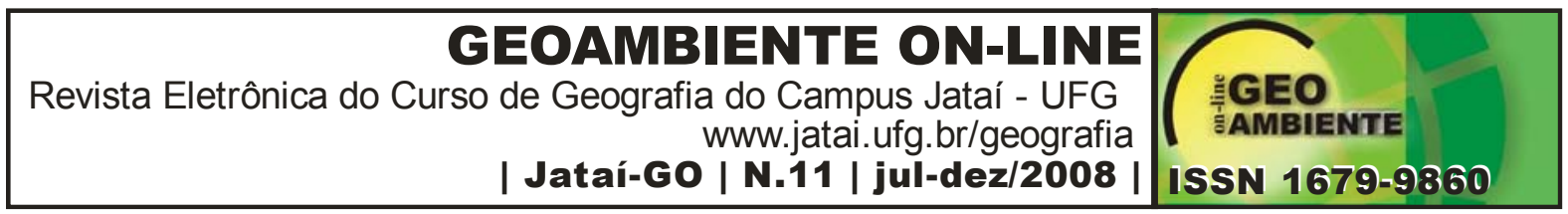

milhões de índios. Nos anos 50, segundo os antropólogos, a população indígena brasileira estava entre 68.000 e 100.000 habitantes. Atualmente, há cerca de 280.000 índios no Brasil, contando os que vivem em centros urbanos, são 350.000 .

A maior parte das terras indígenas $(98 \%)$ está na Amazônia Legal, onde moram 170.000 índios. O maior desafio da atualidade é manter viva a riqueza cultural. Quando os portugueses chegaram ao Brasil, havia em torno de 1.300 línguas indígenas, e hoje existe cerca de 170 . O pior é que cerca de $35 \%$ dos 210 povos com culturas diferentes têm menos de 200 pessoas.

Tendo em vista as grandes diferenças culturais entre os povos do Brasil Amazônico, índios e não índios, é que buscamos um maior entendimento, principalmente sobre os povos indígenas. Sabendo-se que houve e há grandes conflitos entre ambos.

Em LEVI-STRAUSS (1989), as diferenças culturais, índios e não índios são apresentados que durante muito tempo aprouve-nos mencionar línguas às quais faltam termos para exprimir conceitos como o de árvore ou de animal, ainda que nelas se encontrem todos os nomes necessários para um inventário detalhado das espécies e das variedades. Mas ao recorrer a esses casos como apoio de uma pretensa inépcia dos primitivos para o pensamento abstrato, omitia-se outros exemplos que atestam não ser a riqueza em nomes abstratos unicamente o apanágio das línguas civilizadas.

É afirmado em SÓCIO AMBIENTAL (2001), que os índios passaram e passam por grandes dificuldades, tendo muitos problemas com homens da civilização urbana e rural, que buscam riqueza a qualquer custo. Sendo um dos principais agravantes, ocasionando conflitos e mortes, o encontro dos índios com garimpeiros, que é sempre crítico. Há invasão de terras, proliferação de doenças, estímulo à violência e ao alcoolismo e desequilíbrio da estabilidade dos povos, influenciando direta e negativamente na cultura indígena.

Na realidade os índios ainda vivem como antigamente, em comunidade. Partilham o que ganham e produzem coletivamente ajudando tribos vizinhas na caça e na pesca. Entre eles não existe propriedade privada, porque acreditam existir outras coisas com que se preocupar, sendo que uma grande preocupação em várias aldeias hoje, principalmente as de maior proximidades com as cidades, é a falta de comida e a perda dos costumes tradicionais, passados de gerações para gerações. Os índios descobriram como conviver com o branco, ora unindo-se a ele, ora mantendo-se isolado e preservando sua forma de vida, lutando pela sobrevivência fisiológica e cultural. 


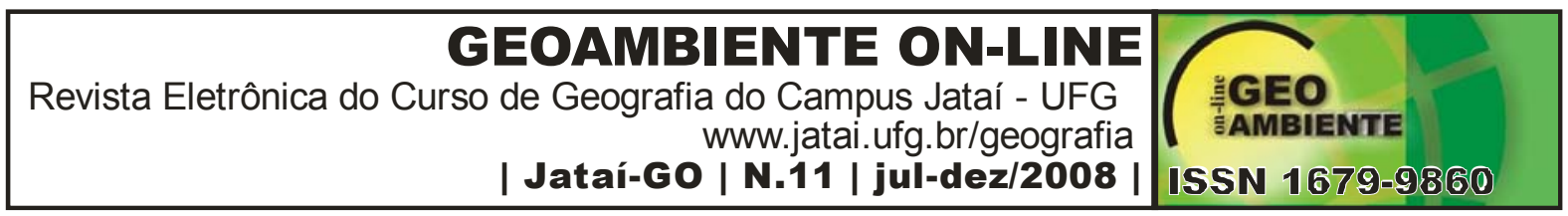

Segundo a citação de GIRALDIN (2004), referenciada no paradigma proposto por (DESCOLA, 1988), em relação à ecologia simbólica podemos distinguir três modos diferentes de identificação dos elementos do meio ambiente: animismo, totemismo e naturalismo.

O animismo é típico da cosmologia não ocidental dota os seres não humanos (animais, plantas e espíritos) de disposições humanas, como também de atributos sociais, chegando, em alguns casos, a conferir-lhes ingredientes culturais, como hábitos, rituais, músicas e danças próprias. Comum nas comunidades tradicionais, essa concepção orienta comportamentos sociais, permite interpretar o acontecimento e tomar decisões.

O totemismo é efetivamente uma lógica classificatória. As diferenças e descontinuidades empiricamente observáveis entre as espécies naturais são tomadas com vistas a organizar a ordem social em suas distintas unidades. Mas, esta identificação dos diferentes grupos, que toma como referência as distintas espécies naturais, em nada conecta seus membros aos seres homônimos da natureza, toma-os simplesmente como referências diferenciadoras do mundo visível para auxiliar na classificação das diferenças sociais.

O naturalismo é a visão ontológica por excelência do pensamento ocidental, visto que os elementos do meio ambiente são pensados como distintos da concepção do homem enquanto ser social. O homem é considerado como especialmente distinto da natureza. Dotado de razão, foi, por isso, o único animal capaz de construir cultura. Dessa maneira, a natureza passa a ser vista como naturalmente existente e anterior à condição humana. Numa situação em que o homem é superior (herança do pensamento cartesiano), essa forma de pensar e agir sobre o meio ambiente tem contribuído para o agravamento da problemática ambiental.

Também podem ser referidas três formas diferentes de relação entre os humanos e o meio ambiente: predação, reciprocidade e proteção.

A predação estabelece-se quando na relação entre humanos e não humanos não se consegue nenhum sistema de troca. É um modo de relação que se observa no animismo, quando, por exemplo, os índios tentam evitar o contacto com o sangue das presas, também buscam ludribiar os espíritos com estratégias semânticas. 


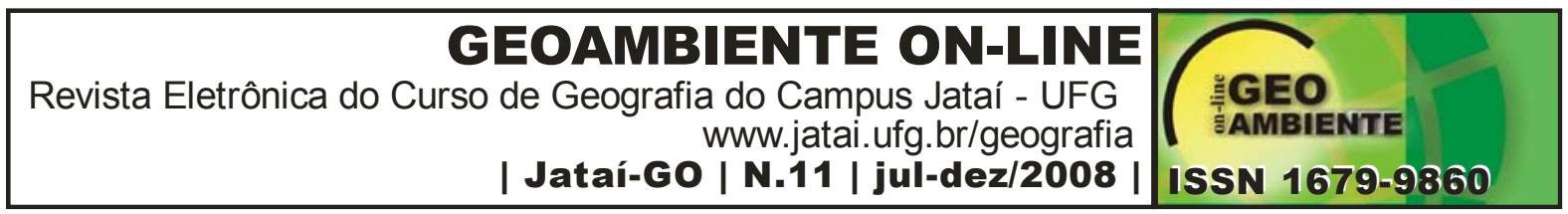

A reciprocidade baseia-se no principio da estrita equivalência entre humanos e não humanos, compartilhando o universo. É um sistema de troca recíproca de alimentos, fluxos vitais e serviços, que se estabelece entre os vários habitantes do cosmos.

A proteção implica um contato direto e permanente com os seres protegidos, é um tipo de dependência entre humanos e não humanos, geralmente recíproca, quando garante uma base de subsistência, um laço emocional, ou um laço com determinada divindade protetora. É um modo de relação que se observa no animismo.

Com base nestes pressupostos podemos caracterizar três povos Amazônicos: Krahô, Juruna e Makuna, buscando mostrar diferenças e similaridades culturais, compilando e descrevendo partes de sua história e localização, sua cosmologia e xamanismo ecologia e caça destes três povos.

\section{2 - HISTÓRICO E LOCALIZAÇÃO DOS KRAHÔ}

Surgiram em Goiás/Tocantins, no século XVIII, as missões religiosas ou aldeamentos, com objetivos de cristianizar os índios e protegê-los contra os assaltos e violências feitas contra as aldeias, realizadas pelos caçadores e escravizadores.

As autoridades administrativas coloniais construíam conjunto de casas no interior de uma paliçada (cercado de madeira) onde os índios viviam confinados e eram obrigados a aprender o catecismo. Nascia ai uma atividade de troca de bens materiais transformando o local em pequenas aglomerações urbanas; como por exemplo, Itacajá.

Os Krahô, atualmente, estão divididos em 16 aldeias, localizadas na região nordeste do estado do Tocantins, próximos a cidade de Itacajá - TO (SALERA JR., 2005). Estes povos estão próximos do rio Manoel Alves, um pequeno afluente do rio Tocantins, pobre em fauna aquática, sendo região de cerrado, sofrendo grande pressão dos fazendeiros e moradores das cidades, principalmente Itacajá, a mais próxima das aldeias.

\section{3 - COSMOLOGIA E XAMANISMO DOS KRAHÔ}

Os Krahô identificam os elementos do meio ambiente pelo sistema anímico, pois eles estabelecem um pacto harmonioso com os espíritos protetores dos animais. Nas aldeias 


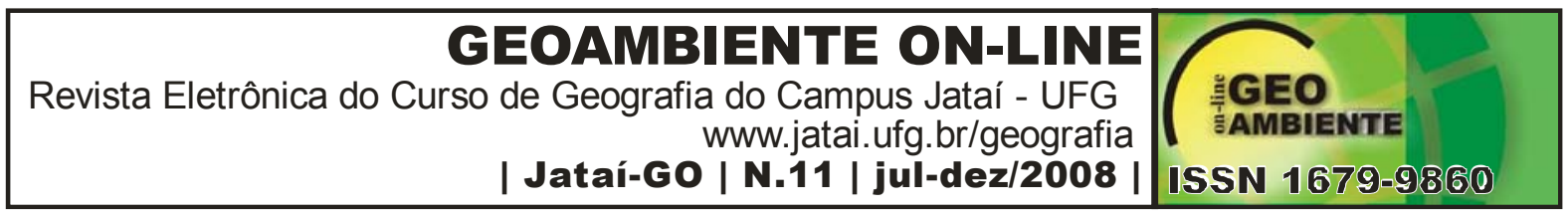

existe um indivíduo que é o feiticeiro, ou xamã, possuidor de poderes sobrenaturais, levando ao desenvolvimento mediúnico, aumentando o seu conhecimento e seu poder de feiticeiro, que pode usar para vários fins, até mesmo para ter sucesso na obtenção de caça para a manutenção da aldeia ou da família dos índios Krahô (alimentação). O xamã entra no mundo dos espíritos, na forma de um espírito semelhante ao da caça desejada, como, por exemplo, o espírito do porcão (queixada), conversa com o protetor dos porcos (espírito), busca todas as informações necessárias sobre os porcos, para então passar essas informações para os caçadores índios, quando ele volta na forma de índio.

Os caçadores, com informações sobre os hábitos dos porcos do mato, sabendo aonde eles vão, onde eles comem, onde eles estão, podem caçá-los e matá-los com facilidade, só não podem é matar em excesso (grandes quantidades), apenas o suficiente para suprir as necessidades da aldeia, ou seja, o que vão comer. Do contrário, o espírito do porcão vem até os índios caçadores e os matam.

O Krahô (Mêry - Homem) antes de ir caçar, participa de um ritual junto com um feiticeiro para ludibriar e matar as suas caças; pois quando ele chega perto da caça, o animal não tem medo do índio, pois pensam que são semelhantes. Muitos desses aspectos são confirmados por MELATTI (1970).

O povo Krahô conhece muitas plantas com poderes diversos (medicinais e sobrenaturais), com vários efeitos, como por exemplo: ervas que amassadas e introduzidas pelas pessoas podem ter êxito satisfazendo as suas necessidades para conseguir uma namorada, para destruir um casamento e abortar (anticoncepcional), analgésico, para viajar nos mundos dos espíritos, para caçar e os animais não fugirem. Podem ser feitos em forma de chá para ser tomado, de vapor para respirarem, de banho para o corpo todo, de fumaça e pó para passarem no corpo e fumarem. Eles também acreditam num deus superior o maior de todos os criadores (Papam).

Há na tradição dos Krahô, na aldeia Manoel Alves Pequeno, aldeia mais próxima da cidade de Itacajá, contos e lendas que tem as suas crenças e mitos mostrando certo animismo. Relatados no mês de outubro/novembro de 2004, algumas dessas histórias:

Um rapaz que vivia na aldeia era solteiro e estava triste, querendo uma companheira; numa noite estrelada ele estava no pátio da aldeia observando o céu estrelado, quando de repente uma estrela desceu do céu na forma de uma linda moça índia, conversou com ele, 


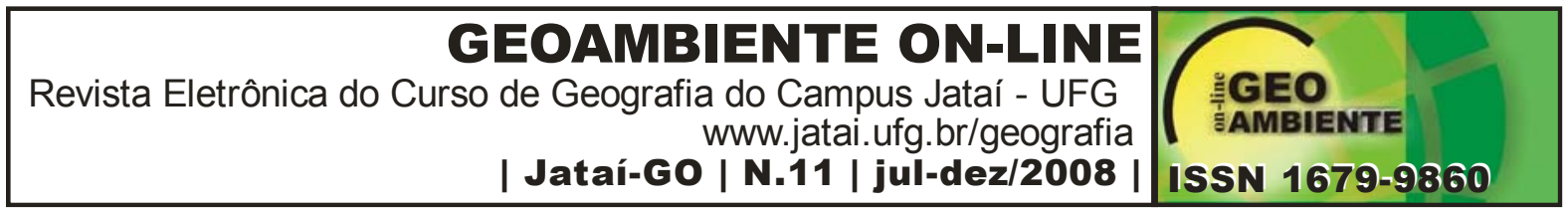

começaram um namoro, logo então se casaram, constituíram família e ali viveram multiplicando os índios Krahô.

A comadre rolinha estava no seu ninho com seus filhotes, no galho de uma árvore, quando, de repente, o compadre raposo apareceu debaixo do ninho dizendo: "comadre rolinha eu quero um filhinho seu para eu comer, pois estou com fome" e a comadre rolinha falou: "não vou te dar meu filhote para o senhor comer" o compadre raposo então falou "se é assim eu vou subir na árvore e vou comer todos os seus filhos" então com muito medo a comadre rolinha jogou em dos seus filhotes para o compadre raposo a comer, o compadre raposo foi embora com a barriga cheia e a comadre rolinha ficou muito triste e resolveu sair para dar uma volta na floresta, quando então olhou para o rio e viu o compadre urubu (tiundi) tomando banho, o compadre urubu também a viu e disse: "olá comadre rolinha, porque a senhora está tão triste" ao que a comadre rolinha respondeu ao compadre urubu: "eu estou triste porque o compadre raposo acabou de comer um filhinho meu e disse "se você não me der um filhinho seu para eu comer eu subo na árvore onde está o ninho da senhora e como todos os seus filhotes, e como até a senhora" então o compadre urubu sorriu e disse: "comadre rolinha o compadre raposo não sabe subir em árvores, ele está mentindo para a senhora só para comer os seus filhotes". A comadre rolinha voltou para o seu ninho pensando nas palavras do compadre urubu. No outro dia o compadre raposo voltou na árvore que se encontrava o ninho da comadre rolinha, e assim falou: "comadre rolinha eu quero outro filhote seu, para eu comer, pois estou com muita fome, se não eu subo e como todos vocês. A comadre rolinha disse: "eu não vou jogar nenhum filhote meu para o senhor pois o senhor não sabe subir em árvores". O compadre raposo muito bravo perguntou: "quem falou isso para a senhora"? Ela então respondeu: "foi o compadre urubu"; imediatamente o compadre raposo saiu à procura do compadre urubu, achando-o no rio a tomar banho, se aproximou e falou para o compadre urubu: "eu vou comer o senhor compadre urubu", assustado o compadre urubu perguntou o porque. O compadre raposo respondeu: "porque o senhor contou para a comadre rolinha que eu não sei subir em árvores". Preocupado e pensativo o compadre urubu respondeu para o compadre raposo: "o senhor não pode me comer, pois estou com as penas molhadas e o senhor vai engasgar com elas, espera-as secarem e ai o senhor pode me comer, eu vou subir naquele toco para me secar no sol", então o urubu se secou e a raposa quis comê-lo, falando para o urubu: "o senhor já esta seco e eu quero comê-lo". O urubu respondeu: "sobe aqui e me come" a raposa pulou algumas vezes, mas não conseguiu subir no toco, pois raposa não sobe em 


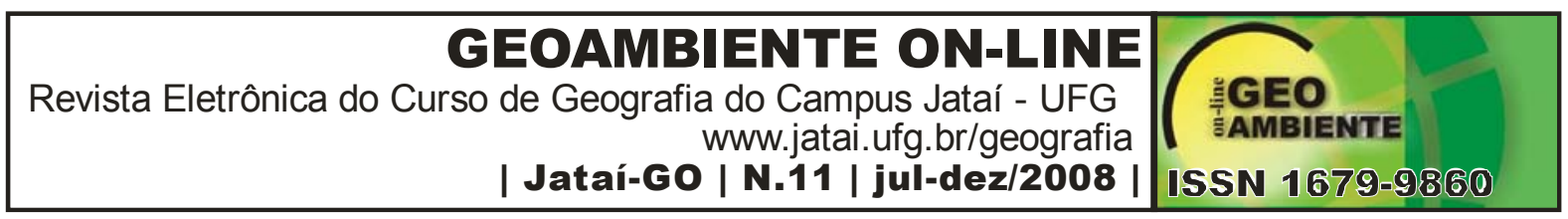

troncos, assim o urubu já com as penas secas voou e foi embora deixando ali o compadre raposo.

\section{4 - ECOLOGIA E CAÇA DOS KRAHÔ}

O Krahô tem como caça predileta a paca e o veado catingueiro, justamente por serem animais típicos do cerrado. Conhecem muitos animais (Priune cune) e seus hábitos, são ágeis na caça com flechas e espingardas, com o auxilio de cachorros (às vezes). As caças mais apreciadas pelos Krahô são: a paca (crã) e o veado catingueiro (cará). Para caça de cará, eles usam o banho feito de uma erva pequena (aproximadamente $50 \mathrm{~cm}$ de altura), que é um dos alimentos do veado (predileto), colocam os galhos, folhas e raízes dentro de uma panela com água sobre as chamas do fogo, deixando-a ferver, espera esfriar e toma o banho com essa mistura, isto é feito uns dez dias antes da caçada, para purificar o corpo. Quando o índio vê o veado ele se aproxima com calma, devagar e com agilidade, sabendo que o animal não vai fugir, pois eles pensam que os índios são veados catingueiros também; então o caçador chega bem perto e atira a flecha ou atira com a espingarda, na parte dianteira (lateral) do animal, pouco atrás da pata dianteira do veado (atingindo o coração). Tendo muito cuidado para não errar o tiro, porque se errar a primeira vez sempre vai errar e os veados não vão mais deixar os índios se aproximarem, mas se acertar da primeira vez o índio sempre vai acertar a caça e a caça jamais fugirá do caçador.

\section{5 - HISTÓRICO E LOCALIZAÇÃO DOS JURUNA}

Canoeiros, os Yudjá são antigos habitantes das ilhas e penínsulas do baixo e médio Xingu, um dos rios mais importantes da Amazônia meridional, atualmente ameaçado por projetos de implantação de complexos hidrelétricos. Desde uns cem anos, este povo acha-se separado em dois grupos por uma enorme distância. Uma parte vive na região de ocupação muito antiga, o médio Xingu, na tão diminuta Terra Indígena Paquiçamba e adjacências não contempladas pelo reconhecimento oficial, bem como em Altamira (Pará). A outra parte vive no alto curso do mesmo rio, na área do Parque Indígena do Xingu (PIX), criado em 1961 no estado do Mato Grosso.

Em SÓCIO AMBIENTAL (2001), basicamente o grupo do PIX representa um dos 14 povos que ali hoje habitam. Suas aldeias estão localizadas na parte norte da Terra 


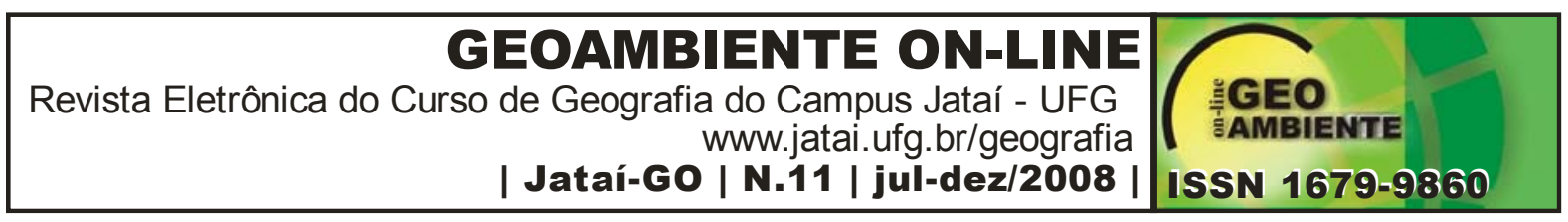

Indígena, entre a BR 80 e o Posto Indígena Diauarum. Neste eixo, as terras da margem ocidental do Xingu pertencem ao município de Marcelândia, e as da margem oriental, a São José do Xingu. Tomando-se um critério lingüístico e em grande medida também cultural, os Yudjá ali possuem quatro aldeias, mas estas, segundo critérios etnopolíticos, poderiam ser reduzidas a uma única: Tubatuba, na foz do Manissauá-Missu. Por razões diplomáticas, em certos contextos as duas aldeias que se formaram por divisão de Tubatuba preferem definirse como "fazendas", e ali são criadas algumas cabeças de gado bovino. A Pequizal é tida ora como uma aldeia Kayabi, por ter um dono que é membro deste povo, como uma aldeia Yudjá devido à língua que ali se fala. Em censo de junho de 2001, os Yudjá somavam cerca de 270 pessoas.

\section{6 - COSMOLOGIA E XAMANISMO DOS JURUNA}

Para os Juruna a identificação dos elementos do ambiente é feita pela modalidade totêmica, acreditando que os animais são humanos. Tendo uma relação virtual de afinidade muito forte relacionada aos animais. Seus habitantes sempre se pintam de jenipapo e adornados com penas de pássaros, tendo alguns exemplos de alimentos rituais: répteis, mamíferos, peixes e o mingau alcoólico, que faz parte da vida ritual Juruna, mostrando simbolismos religiosos e guerreiros. As diferenças entre as espécies naturais são apropriadas pela sociedade e usadas para marcar as diferenças entre os grupos sociais.

Para VIVEIROS DE CASTRO (1996), o modelo por excelência das categorias relacionais são os pronomes da primeira e da segunda pessoa, como eu e tu, chamando a atenção para a estranha facilidade com que os humanos podem cair em processos alienantes.

Parte do saber cosmológico e da vida ritual depende de modo crucial dos xamãs (curandeiros - feiticeiros), e não existem mais xamãs entre os Yudjá desde os anos 1980. Algumas pessoas tentaram, fazendo uso dos remédios apropriados, mas faltou-lhes coragem, desistiu com medo, como relatou o capitão em 1989: "Eu me defrontei com uma onça e não quis preparar o remédio (arïpa) de novo. Tive medo que acontecesse outra vez. Acho perigosa - a onça brincou comigo! Bebi apenas um pouquinho e tomei um único banho do remédio. Depois de alguns dias fui pescar, e a onça avançou em minha direção na hora em que flechei um tucunaré. Aproximou-se de mim e me mostrou os dentes, peguei o arco, tentei bater nela, mas correu. Eu não tinha flecha de caça; e minhas flechas de pesca, duas apenas, nem as tinha arrancado dos peixes ainda. Foi um perigo! Pensei que ia me pegar. 


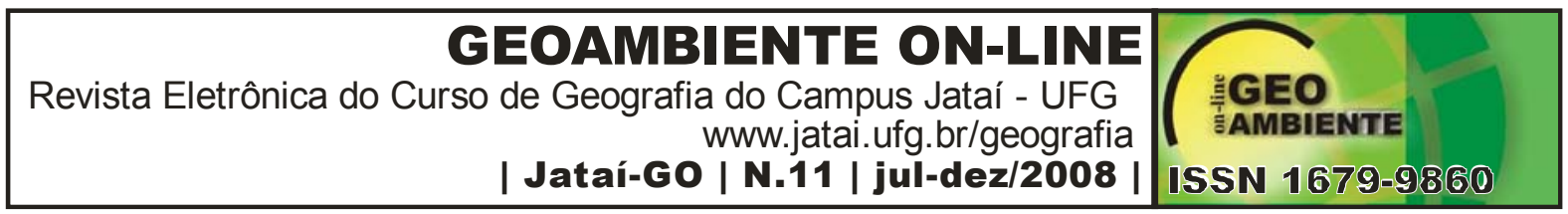

Por isso peguei o arco e brandi, a onça recuou um pouco e ficou me fitando. Arranquei as flechas dos peixes, matei-os e disse à onça, venha de novo! Pretendia flechá-la, mas foi embora. É muito perigoso! Se fosse em sonho, tudo bem, se a onça me aparecesse dizendo que está brincando comigo, tudo bem”. Mas não foi em sonho" (SÓCIO AMBIENTAL, 2001).

De acordo com LIMA (1996), os Juruna, dizem que quando uma pessoa comum sonha com um jaguar, equivalente ameaçador selvagem na experiência onírica do xamã, o sonho significa na vida desperta que se será atacado por índio selvagem. Os Yudjá procuram os serviços terapêuticos de xamãs Kayabi, e, mais raramente, Kamayurá (quando se trata de desenfeitiçamento).

A partir de 1987, algumas pessoas, mulheres e homens, receberam de xamãs Kayabi o poder de curar, e vêm efetuando uma terapia xamânica simplificada. Sem terem passado por qualquer aprendizado mais formal do xamanismo Kayabi, sua prática alia a noção de um poder obtido junto a forças cósmicas estrangeiras a teorias próprias das doenças, das quais a mais importante afirma que elas derivam em última instância da ação humana: as forças despendidas pelas pessoas sobre as coisas são replicadas pelas almas no corpo das pessoas ou de parentes seus. Cabe ao xamã extrair tais doenças. Três são as coordenadas fundamentais da cosmologia Yudjá:

A oposição entre vida e morte, em primeiro lugar; ela está longe de ser uma dicotomia tão drástica como afirma a nossa cosmologia, pois há algumas transições cruciais engendradas pelo funcionamento dinâmico da máquina cosmológica, desde algo como pequenas mortes passageiras, provocadas pelo sono e cuja expressão mais típica são os sonhos, até mortes antecipadas. A relação entre vida e morte é menos de exclusão recíproca (se está morto, não pode estar vivo) que de inclusão: ele está morto aqui, mas vivo em outro lugar; aqui ainda está vivo, mas já morreu no além. Em outras palavras, trata-se de uma relação de disjunção relativa, capaz de dar lugar a conjunções importantes. Os xamãs Yudjá eram os mestres dessas transições (AMBIENTE BRASIL, 2000).

Em segundo lugar, os eixos do mundo são dados pelas oposições entre Rio e Floresta e Céu e Terra, cada uma articulada à oposição entre presença e ausência de antropofagia. $\mathrm{O}$ Rio e o Céu têm uma ligação positiva com a última. Dir-se-ia que todas as coisas que existem poderiam ser duplicadas a partir de tais oposições: os humanos (os povos do rio e os da floresta), os espíritos dos mortos (os dos grandes rochedos da beira do Xingu, que não 


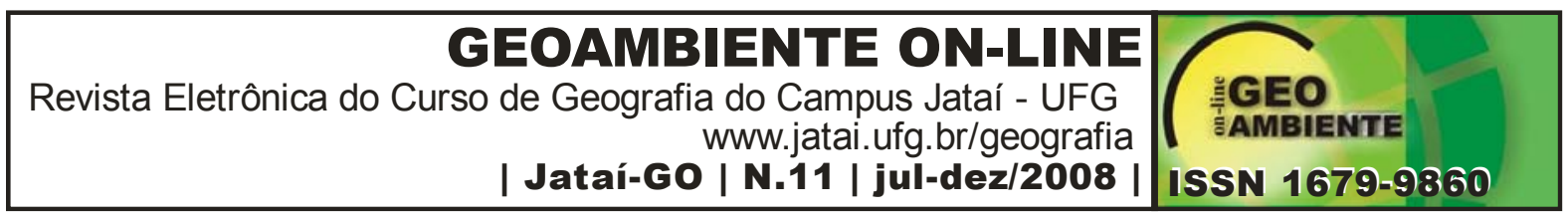

gostam de carne de gente, e os do céu), os animais mamíferos (as espécies da floresta e seus correspondentes isãmï do fundo do rio), os Yudjá e seus correspondentes ãwã do fundo rio, os Abi da floresta e seus correspondentes ãwã dos locais sujos e sombrios da mata longínqua. Além disso, considera-se que todos os tipos de coisas existentes na terra existem também no céu (esta é uma terra parecida com a nossa). Já o rio, que não é para os Yudjá cópia da floresta, pode ser tido como uma cópia da terra por certos de seus habitantes, exceto que a floresta da terra deles é a nossa floresta de galeria, e as suas roças são terrenos desmoronados da beira do rio.

A terceira e última operação cosmológica fundamental repousa sobre a oposição entre o ponto de vista do sujeito humano vivo e desperto e pontos de vista alheios, como o de animais, animais-isãmï, ãwãa, e finalmente o dos 'i'ãnay (os mortos). O dinamismo e a complexidade da cosmologia Yudjá dependem estreitamente do confronto, virtualmente perigoso, desses pontos de vista discordantes.

O xamanismo Yudjá desdobra-se em dois sistemas relacionados cada um com uma sociedade de mortos. Considera-se rara a possibilidade de um xamã praticar os dois xamanismos: os mortos dos rochedos temem por demais os do céu, cuja sociedade é formada pelas almas dos guerreiros em torno do capitão e xamã Kumahari. Um pavor talvez ainda maior experimenta hoje os Yudjá por eles, e este xamanismo é incrivelmente mais poderoso, perigoso e difícil de se obter.

Cada sistema estava relacionado a um grande festival em honra de sua respectiva categoria de mortos. $\mathrm{O}$ dos mortos dos rochedos ('i'ãnay karia) desenvolvia-se ao som de música de flautas e cantos executados por eles próprios, soprados na boca do xamã. Aquele chamado duru karia (ou 'e'ãmï karia) desenvolvia-se ao som da música de um conjunto de trombetas (duru). Em sua festa, Kumahari e seus associados, à comida oferecida pelos Yudjá, preferiam comer a carne de Índio assada trazida do além; recusando também o cauim, diziam que já estavam bastante bêbados. Já os hóspedes provenientes dos rochedos, após a refeição, bebiam bastante, temperando o cauim das mulheres Yudjá com uma porção de cauim trazido do além. Ambos os festivais duravam em torno de um mês, e seu encerramento motivava a participação de diferentes aldeias. As últimas celebrações foram realizadas nos idos da década de 1970.

Nem por isso, contudo, a vida ritual dos Yudjá pode-se dizer que não é bastante intensa. Além de sua rotina ser interrompida por cauinagens a intervalos tão curtos como 


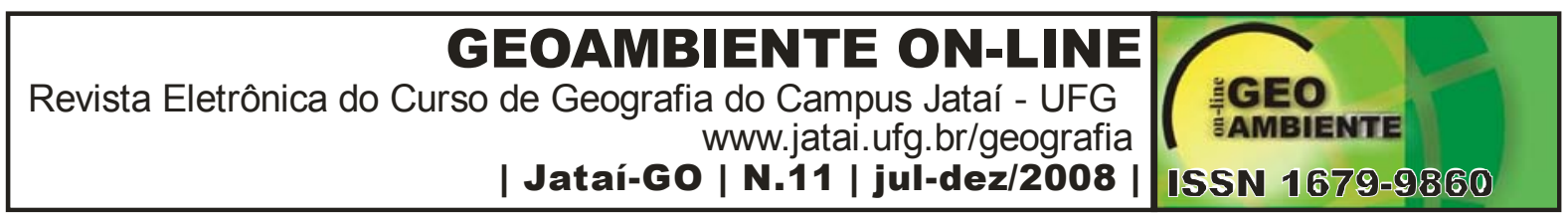

quatro ou cinco dias, celebram todo ano dois festivais (tendo cada um a duração aproximada de um mês).

Segundo a mitologia, de uma humanidade celeste, imortal (os alapa), provêm os cantos do festival das plantas cultivadas (koataha de abïa), controlado pelas mulheres. Aos $\tilde{a} w \tilde{a}$ produtores de cauim que vivem em aldeias localizadas no fundo do rio e lagoas, os Yudjá devem dois festivais de clarinetas (pïri), bem como os adornos corporais que servem de distintivos étnicos: a penugem de pato colada nos cabelos e o botão vermelho colado no alto da testa feito de almécega e fiapinhos de tecido vermelho picotado. Nenhum desses três festivais tem, é certo, a mesma importância cosmológica dos rituais xamânicos, mas são dotados de grande valor social.

\section{7 - ECOLOGIA E CAÇA DOS JURUNA}

Em LIMA (1996), um dos efeitos do paralelismo sobre o conjunto da cosmologia é uma interessante relação virtual de afinidade potencial com a caça. Aplicada sobre tudo aos porcos do mato, os Juruna não se supõe aqueles de cujo ponto de vista essa relação duplamente metafórica encontra sua justificação. Os Yudjá baseiam sua subsistência essencialmente no cultivo de roças - a mandioca é seu principal produto - e na pesca com arco e anzol, embora apreciem muito a carne de caça. A estação da caça começa após a derrubada das roças e prossegue até o início das chuvas, quando é preciso realizar a queimada (em setembro), sendo que hoje em dia as pessoas não quererem mais se dedicar às longas viagens de canoa no período das águas baixas para caçar e acampar nas praias que afloram no Xingu.

Até recentemente as pessoas investiam bastante desejo na navegação. No período 1984-1990, a maioria dos homens tinha duas ou mesmo três canoas, uma menor para a pesca, outra maior para viajar. Em 2001, vários eram aqueles que não tinham nenhuma canoa, e, no porto de Tubatuba, as canoas existentes eram trancadas com cadeado, pois os donos queriam evitar aborrecimento por não encontrar a sua na hora de ir pescar. Das canoas de viagem com capacidade para 15 ou mais pessoas não havia um único exemplar. Provavelmente essas transformações ocorreram pela imposissão da modernidade e a relação com o Homem da urbanizado. 


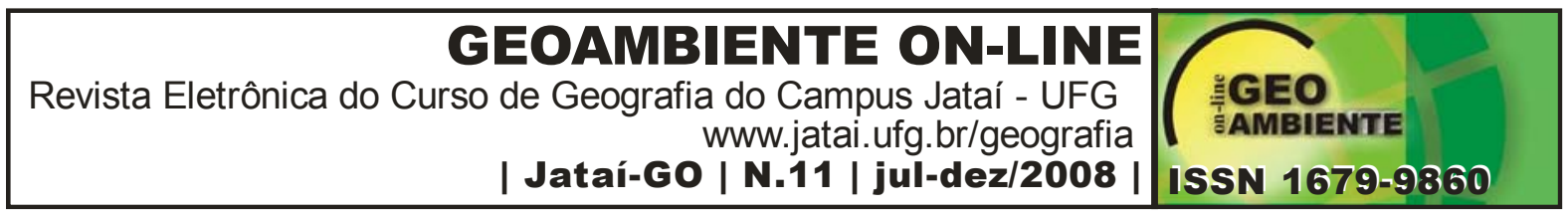

\section{8- HISTÓRICO E LOCALIZAÇÃO DOS MAKUNA}

Localizados no alto rio negro, noroeste amazônico, o principal rio que corta essa região é o Negro, afluente do Amazonas que, antes de entrar no Brasil, tem o nome de Guainía e separa a Colômbia da Venezuela. No seu alto curso, ele recebe, pela margem direita, o Içana e o Uaupés (chamado de Vaupés na Colômbia). Abrange também o Rio Apapóris e seus afluentes, tributários quase inteiramente colombianos do Caquetá, uma vez que desemboca neste último após marcar um pequeno trecho da fronteira com o Brasil. Daí para baixo, o Caquetá passa a denominar-se Japurá.

A bacia hidrográfica do Rio Içana tem suas nascentes na Colômbia, mas logo em seguida passa a delimitar a fronteira com o Brasil, adentrando o território brasileiro na direção sudoeste depois de um pequeno trecho. A extensão do Içana é de cerca de $696 \mathrm{Km}$. Já o Rio Uaupés tem cerca de $1.375 \mathrm{Km}$ de extensão. Depois do Rio Branco, o Uaupés é o maior tributário do Rio Negro e, em seu curso, também recebe as águas de outros grandes rios, como o Tiquié, o Papuri, o Querari e o Cuduiari. Acima da foz do Uaupés fica a área formada pelo Rio Xié e alto curso do Rio Negro.

A maior parte da região é constituída por terras da União (Terras Indígenas e um Parque Nacional). A população indígena atual constitui pelo menos $90 \%$ do total, embora os mais de dois séculos de contato e comércio entre os povos nativos e os "brancos" tenha forçado a ida de muitos índios para o Baixo Rio Negro ou para as cidades de Manaus e Belém, bem como levadas pessoas de outras origens a se estabelecerem ali. Há presença de nordestinos, paraenses e pessoas de outras partes do Brasil e do Amazonas que se concentram nos poucos centros urbanos regionais.

No Brasil, as etnias do Alto Rio Negro se encontram em oito Terras Indígenas cinco delas homologadas e contíguas, duas ainda a identificar e uma em identificação situadas nos municípios amazonenses de São Gabriel da Cachoeira, Japurá e Santa Isabel (AMBIENTE BRASIL, 2000).

\section{9 - COSMOLOGIA E XAMANISMO DOS MAKUNA}

Os Makuna são da modalidade anímica na identificação dos elementos do meio ambiente, os seus xamãs realizam rituais no qual pedem autorização aos donos espirituais dos animais para caçar ou pescar. Em troca oferecem comida espiritual. 


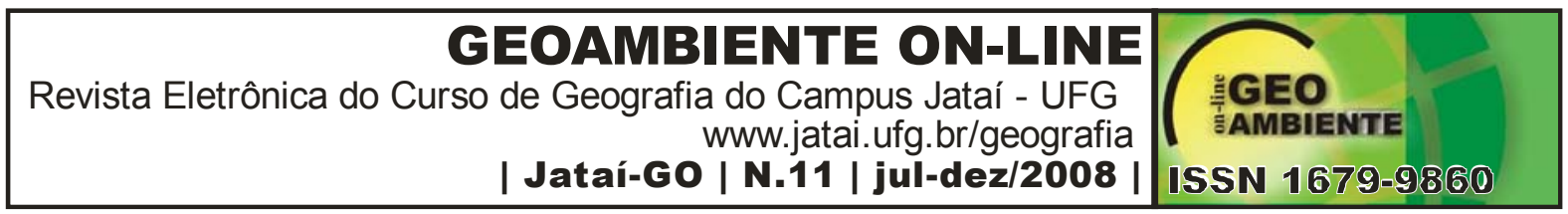

É característico da região um complexo ritual envolvendo o uso de flautas e trombetas sagradas, associadas a uma mitologia cujos temas centrais incluem a iniciação, os ancestrais, a guerra e os ciclos sazonais. Por meio dos poderes do xamanismo, de substâncias alucinógenas e do contato com os instrumentos musicais, os participantes desses cerimoniais vão ao encontro do passado mítico e a estrutura social ganha maior visibilidade (SÓCIO AMBIENTAL, 2001).

Há divisões de trabalho entre os homens e as mulheres, cabendo aos homens a contribuição com a manutenção alimentar, o peixe ou a carne de caça. Em geral, os homens saem de canoa todos os dias ou durante a noite para pescar ou caçar. Também desmatam e fazem as queimadas das áreas de floresta ou de capoeiras velhas para a constituição das roças. A partir de então, o trabalho torna-se feminino, desde a escolha das variedades de mandioca ou das outras espécies cultivadas até o preparo dos alimentos.

O universo destes povos é feito de três camadas básicas: céu, terra e "mundo inferior". Cada camada é um mundo em si, com seus seres específicos e podendo ser entendidos tanto em termos abstratos como concretos. Em contextos diferentes, o "céu" pode ser o mundo do sol, da lua e das estrelas, ou o mundo dos pássaros que voam alto, ou os topos achatados dos tepuis (topos achatados das montanhas) dos quais descem as águas ou o mundo dos topos das árvores da floresta, ou mesmo uma cabeça enfeitada com um cocar de penas vermelhas e amarelas de arara, que são as cores do sol. Do mesmo modo, o "mundo inferior" pode ser o Rio dos Mortos debaixo da terra, o barro amarelo debaixo da camada do solo onde se enterram os mortos, ou o mundo aquático dos rios subterrâneos.

De toda forma, o que define o "céu" ou o "mundo inferior" depende não somente da escala e do contexto, mas também da perspectiva: à noite o sol, o céu e o dia ficam debaixo da terra e o escuro mundo inferior fica acima. Há uma história sobre um homem que encontra o cadáver de uma mulher-estrela que caiu na terra quando fora enterrada por sua família no céu: para seus parentes ela está morta no mundo inferior; para o homem, ela está viva na terra. O homem casa com a mulher-estrela e vai com ela visitar sua família no céu. Para o homem, as estrelas são os espíritos dos mortos que vivem à noite; para as estrelas, ele que é um espírito, e o dia para ele corresponde à noite para elas (AMBIENTE BRASIL, 2000). 


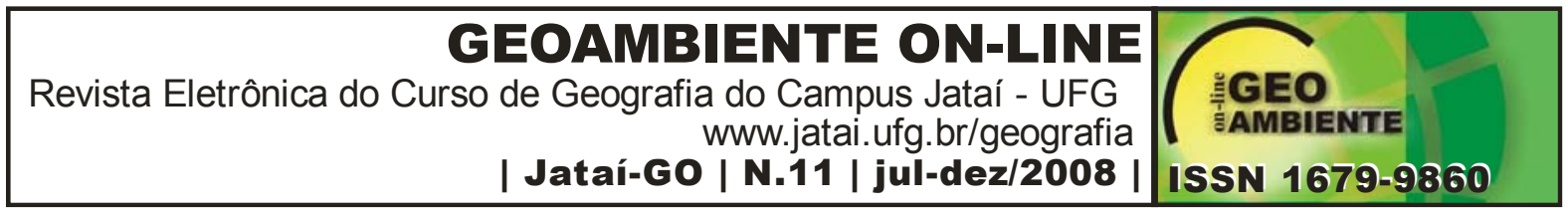

Os alimentos mais consumidos pelos Makuna são: a mandioca e o peixe pirarucu, pescado no rio Negro, que é o maior rio de águas pretas do mundo. Os especialistas caracterizam estas águas como extremamente ácidas e pobres em nutrientes. As terras que drenam são de solos muito empobrecidos e lixiviados. Esta pobreza em nutrientes dos rios influi na vida dos peixes, que, para se sustentar, obtêm a maior parte de sua alimentação de matéria orgânica oriunda principalmente das margens dos rios (vários tipos de insetos, frutas, flores, folhas e sementes). O contrário acontece nos rios de águas brancas, que são ricos em nutrientes, como é o caso do Amazonas e do Solimões. Estas condições do ambiente fluvial também influenciam na composição das espécies de peixes. Apesar de algumas de grande porte, como o pirarucu, os rios da bacia do Rio Negro se caracterizam por um grande número de espécies menores, cada qual com um pequeno número de indivíduos (SÓCIO AMBIENTAL, 2001).

A exploração econômica de faixas ecológicas diferenciadas impulsiona as relações de trocas econômicas e rituais entre as várias populações indígenas; a ênfase na agricultura da mandioca brava através do sistema de coivara, que consiste na derrubada de uma área de floresta primária ou capoeira alta, que então é deixada para secar e depois queimada. As roças plantadas nestas clareiras, produtivas durante dois a três anos, são gradualmente abandonadas, embora ainda visitadas para a coleta de frutos de ciclo mais longo. Cada família possui, no mínimo, três roças em diferentes estágios de seu desenvolvimento, além de continuarem a explorar suas capoeiras.

Os roçados em geral são abertos em áreas de terra firme, longe das margens dos rios, de modo a preservar as principais fontes alimentícias de origem pesqueira; a alta especialização das técnicas de pesca (armadilhas fixas como paris, matapis ou cacuris) e o conhecimento profundo das estações através de um elaborado calendário astronômico permitem acompanhar e aproveitar o regime de cheias e vazantes dos rios e os ciclos migratórios, reprodutivos e alimentícios dos peixes.

\section{1 - CONSIDERAÇÕES FINAIS}

Diante das observações feitas neste trabalho pode ser descrito que os povos Krahô, Juruna e Makuna estão localizados na região norte do Brasil (região Amazônica), a região mais rica em biodiversidade do Brasil. Os Juruna e Makuna são povos da floresta Amazônica (estado do Pará e Amazonas, respectivamente), onde pode ser encontradas 


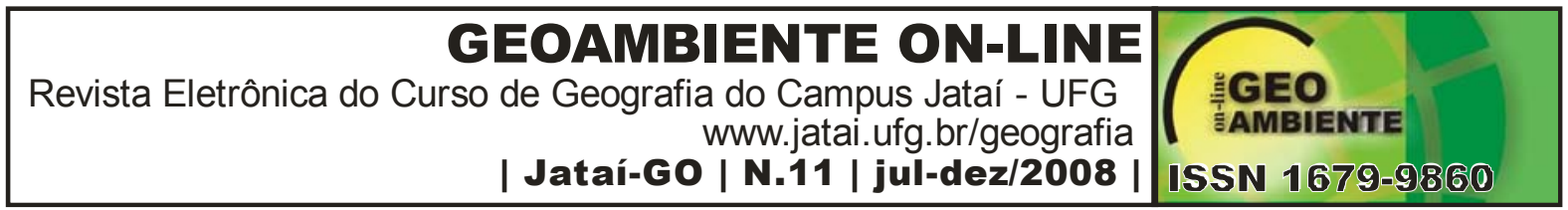

variedades da fauna e flora brasileira em abundância, pois é a maior floresta tropical úmida do planeta. Estas duas etnias estão na margem de dois grandes rios da bacia Amazônica (maior bacia do mundo), respectivamente rio Xingú e Negro, que têm uma rica fauna aquática. Já os Krahô, estão próximos do rio Manoel Alves (aproximadamente dois km de distância), um pequeno afluente do rio Tocantins (estado do Tocantins), sendo este pobre em fauna aquática, sendo que eles vivem numa região de bioma caracterizado cerrado, próximo da cidade de Itacajá, sofrendo influência da civilização ocidental; sendo que esta proximidade perturba a incidência e disponibilidade de caça.

Os Krahô têm como caça predileta a paca e o veado catingueiro, justamente por serem animais típicos do cerrado e pelo fato de estarem presentes nesta região, próximos da cidade. Quase não pescam, coletam frutos nativos e cultivam mandioca (principal fonte de subsistência).

Já os Juruna, com uma grande biodiversidade disponível (grande quantidade de caça e pesca), não utilizam a diversidade desta, pois exploram apenas algumas espécies de animais (peixes e caça), sendo sua principal fonte de subsistência o cultivo da roça de mandioca.

Os Makuna que vivem nas margens do rio Negro, um rio onde os recursos de pesca não são muito abundantes quando comparados com rios de águas brancas (Solimões), pelo fato das suas águas serem negras e com poucos nutrientes: tendo em especial um peixe de grande porte muito apreciado pelos Makuna - o pirarucu (Apaiama gigas). Eles têm o habito de caçar e pescar, mas a sua principal fonte alimentícia é a mandioca, sendo também coletores de frutos nativos. Características essas (cultivo da mandioca e coleta de frutos), comuns entre os três povos descritos.

Os Krahô identificam os elementos do meio ambiente pelo sistema anímico, pois eles estabelecem um pacto harmonioso com os espíritos protetores dos animais. O mesmo se passa com os Makuna uma vez que os seus xamãs realizam rituais no qual pedem autorização aos donos espirituais dos animais para uma caça, ou pesca mais extensa, em troca oferecem comida espiritual.

No caso dos Juruna a identificação dos elementos do meio ambiente é feita pela modalidade totêmica, uma vez que os Juruna acreditam que os animais são humanos, mas não humanizam os animais, mostrando a diferença da cosmologia Juruna relacionadas aos Makuna e Krahô. 


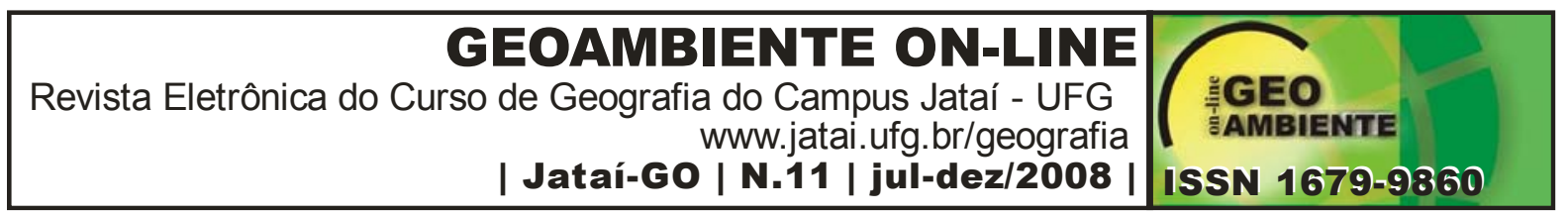

\section{2 - Referências Bibliográficas}

AMBIENTE BRASIL. Indios do Brasil. 2000

DAMATA, R. Relativisando uma introdução a Antropologia Social. Editora Rocco LTDA. Rio de Janeiro- RJ. 2000.

DESCOLA, P. La selva culta. Simbolismo y praxis en la ecología de los Achuar. Lima/quito:IFEA ( Instituto Frances de Estudios Andinos)/Ed. Abya Yala. 1988.

GIRALDIN, O. Os filhos plantados: a relação Apinajé com as plantas cultivadas. II encontro regional de Historia. Anpuh-BA. 2004.

LEVI-STRAUSS, C. O Pensamento selvagem. Campinas-SP, Papirus. 1989.

LIMA, T. S.. Para uma teoria etnografia da distinção natureza e cultura na cosmologia juruna. XXII ${ }^{\circ}$ Encontro Anual da ANPOCS. GT Etnologia Indígena. 1996.

MELATTI, J.C. Índios do Brasil. 2 ed. rev. Brasília: Coordenada. 236p. 1972.

MELATTI, J.C. 1970. O sistema social Krahô. São Paulo: USP. 530p. (Tese de Doutorado).

SALERA JR., G. Avaliação da biologia reprodutiva, predação natural e importância social em quelônios com ocorrência na bacia do Araguaia. Palmas, Universidade Federal do Tocantins. (Dissertação de Mestrado em Ciências do Ambiente - Universidade Federal do Tocantins). 191p. 2005.

SÓCIO AMBIENTAL. Enciclopédia povos indigenas da Amazônia. Noroeste Amazônico. 2001 .

SÓCIO AMBIENTAL. Enciclopédia povos indigenas do Brasil. Brasil ISA. 2001.

VIVEIROS DE CASTRO, E.. Os pronomes cosmológicos e o prespectivismo ameríndio. Mana, 2 (2): 115-144. 1996. 